\title{
Egg characteristics of New Hampshire laying hens from floor and organic rearing systems
}

\author{
Simeon Rakonjac ${ }^{1}$, Snežana Bogosavljević-Bošković ${ }^{1}$, Zdenka Škrbić ${ }^{2}$, \\ Miloš Lukić ${ }^{2}$, Vladimir Doskovići ${ }^{1}$, Milun D.Petrović ${ }^{1}$, Veselin \\ Petričević $^{2}$ \\ ${ }^{1}$ University of Kragujevac, Faculty of Agronomy Čacak, Serbia \\ ${ }^{2}$ Institute of Animal Husbandry, Belgrade-Zemun, Serbia \\ Corresponding author: simcepb@yahoo.com
}

\begin{abstract}
The aim of this study was to compare the effect of two alternative rearing systems (floor and organic) on egg quality traits of New Hampshire laying hens in three different phases of the productive cycle (32, 48 and 72 weeks of age). Egg samples (15 eggs per group) were analysed for quality (egg weight, egg shape index, albumen height, Haugh unit, yolk colour) and chemical composition (dry matter, minerals, proteins and lipids). Egg weight, dry matter and protein content increased, while albumen height, Haugh unit and lipid content decreased with hen age $(\mathrm{p} \leq 0.05)$. Eggs from the floor rearing system had a higher shape index and lipid content compared to organic eggs $(p \leq 0.05)$. Both factors and their interactions had a significant effect on yolk colour $(\mathrm{p} \leq 0.05)$.
\end{abstract}

Keywords: New Hampshire, rearing systems, egg quality, chemical composition, laying hen age.

\section{Introduction}

The number of laying hens reared in non-cage production systems is constantly increasing in Europe, already reaching about 50\% in the United Kingdom while keeping hens in cages is even forbidden in some countries 
(Switzerland, Norway) (Rakonjac et al., 2018a). There are two main reasons for the introduction of these alternative rearing systems: the production of better and healthier products for human consumption and the provision of a higher level of well-being for hens.

The introduction of new rearing systems has inevitably raised the question regarding the choice of genotypes to be used in this production. Namely, modern hybrids have been selected for the cage production system, which implies a fully controlled environment (temperature, light, humidity) and no risk of exposure to potential disease agents, parasites or predators. Feed for these layers must contain a high level of energy, vitamins, proteins and, in particular, some limiting amino acids, which in alternative rearing systems (especially organic) is not easy to provide. There are health and welfare risks associated with keeping high yielding hens in outdoor systems (Van de Weerd et al., 2009).

For this reason, pure breed hens can be used in free-range production systems as they are better adapted to free-range, are capable of producing on a less protein-rich diet, and have a satisfactory behaviour and reasonable productivity (Sørensen et al., 2004). The use of these breeds, which still have natural behaviours, could also be a valuable alternative, particularly if they are in danger of extinction (Mugnai et al., 2009).

There are a few studies on the effect of alternative rearing systems on egg quality traits of pure breed hens (Rizzi and Chiericato, 2005; Mugnai et al., 2009,) and on the effect of hen age on these parameters (Zita et al., 2009; Chung and Lee, 2014), but the joint effect of rearing system and hen age for pure breeds is not fully known. Therefore, the aim of this study was to compare the effect of two alternative rearing systems (floor and organic) in three different phases of the productive cycle on egg quality traits of New Hampshire layers.

\section{Material and method}

The study involved a total of 60 New Hampshire laying hens reared under floor and organic systems (30 birds per group). New Hampshire is a dual-purpose breed (for eggs and meat) and is suitable for non-intensive rearing conditions.

In both rearing systems, stocking density was $2.5 \mathrm{birds} / \mathrm{m}^{2}$. Organic layers were provided with $5 \mathrm{~m}^{2}$ of outdoor natural grassland area per bird, and these hens were able to supplement their diets using vegetation and small creatures living on free range.

Laying hens were fed diets whose average chemical compositions are shown in Table 1. In the organic system, except in the facility, feeders and drinkers were located outdoors. It is important to note that the diet for organic hens contained no synthetic amino acids, vitamins and minerals, and had more than $80 \%$ organically grown components. In all experimental groups, feed and water were available ad libitum. 
Table 1. The chemical composition of diet for laying hens

\begin{tabular}{|c|c|c|}
\hline & Floor system & Organic system \\
\hline Chemical composition & $\%$ & $\%$ \\
\hline Dry matter & 88.38 & 89.82 \\
\hline Crude proteins & 16.79 & 16.82 \\
\hline Crude fats & 5.15 & 4.31 \\
\hline Cellulose & 4.82 & 4.29 \\
\hline Ash & 12.52 & 12.68 \\
\hline Ca & 3.72 & 3.43 \\
\hline Total P & 0.71 & 0.81 \\
\hline Na & 0.17 & 0.18 \\
\hline Lysine & 0.79 & 0.80 \\
\hline Methionine+cystine & 0.68 & 0.48 \\
\hline Metabolisable energy MJ & $11.5 \mathrm{MJ}$ & $11.3 \mathrm{MJ}$ \\
\hline
\end{tabular}

Eggs were collected for analyses in three phases of the productive activity (at the beginning of the laying period -24 weeks of hen age, in the middle of the laying period -48 weeks of hen age, and at the end of the laying period -72 weeks of hen age). These samples (eggs were one-day old) were analysed for external and internal quality parameters and chemical composition of eggs.

- Egg weight was measured on an electronic scale with an accuracy of $10^{-2} \mathrm{~g}$.

- Egg shape index, or short-axis to long-axis length ratio (\%), was determined using a special device (B.V. Apparatenfabriek van Doorn, Holland).

- Albumen height was determined by a tripod micrometer (AMES, USA)

- Haugh units were calculated according to the following formula:

$\mathrm{HU}=100 \log \left(\mathrm{H}+7.57-1.7 \mathrm{M}^{0.37}\right)$

where $\mathrm{H}=$ albumen height, $\mathrm{mm} . \mathrm{M}=$ egg weight, $\mathrm{g}$.

- Egg yolk colour was determined according to the Roche yolk colour fan.

The chemical composition of eggs was determined according to AOAC procedures (AOAC, 1990).

Egg quality data were analysed by ANOVA and LSD test (Stat Soft Inc Statistica for Windows. Version 7.0., 2006).

\section{Results and discussion}

At 48 and 72 weeks of hen age, eggs had greater weights $(\mathrm{p} \leq 0.05)$ than at the beginning of the production cycle ( 24 weeks), which is consistent with the results published by Rakonjac et al. (2017 and 2018b). Padhi et al. (2013) found that egg weight increased only at the beginning of egg production while it remained unchanged in later phases. Calik (2011) determined that the weight of eggs from New Hampshire layers ranged from 59.3 to $60.9 \mathrm{~g}$ at 30 weeks of hen age, which is in line with the tendency of egg weight to increase with ageing, as determined 
in our research. On the other hand, there was no significant difference in egg weight between floor and organic eggs ( $\mathrm{p} \geq 0.05)$, similarly to the results reported by Mugnai et al. (2009) and Rakonjac et al. (2017).

Table 2. Effects of rearing system and hen age on egg quality characteristics

\begin{tabular}{|c|c|c|c|c|c|c|}
\hline $\begin{array}{c}\text { Rearing } \\
\text { system } \\
(\mathrm{RS})\end{array}$ & $\begin{array}{c}\text { Hen age } \\
\text { (HA) } \\
\text { (weeks) }\end{array}$ & $\begin{array}{c}\text { Egg } \\
\text { weight } \\
(g)\end{array}$ & $\begin{array}{l}\text { Egg } \\
\text { shape } \\
\text { index }\end{array}$ & $\begin{array}{c}\text { Albumen } \\
\text { height } \\
\text { (mm) }\end{array}$ & $\begin{array}{c}\text { Haugh } \\
\text { unit }\end{array}$ & $\begin{array}{c}\text { Yolk } \\
\text { colour } \\
\text { (Roche) }\end{array}$ \\
\hline \multirow{3}{*}{ Floor } & 24 & $51.81^{b}$ & $76.07^{\mathrm{a}}$ & $86.47^{\mathrm{a}}$ & $93.40^{\mathrm{a}}$ & $10.73^{c}$ \\
\hline & 48 & $66.07^{\mathrm{a}}$ & $75.53^{\mathrm{ab}}$ & $76.13^{b}$ & $84.47^{b}$ & $11.47^{\mathrm{b}}$ \\
\hline & 72 & $65.71^{\mathrm{a}}$ & $75.80^{\mathrm{ab}}$ & $61.80^{c}$ & $73.93^{\mathrm{c}}$ & $13.73^{\mathrm{a}}$ \\
\hline \multirow{3}{*}{ Organic } & 24 & $51.39^{b}$ & $74.40^{\mathrm{ab}}$ & $86.73^{\mathrm{a}}$ & $94.67^{\mathrm{a}}$ & $11.20^{\mathrm{bc}}$ \\
\hline & 48 & $66.84^{\mathrm{a}}$ & $74.07^{\mathrm{b}}$ & $81.80^{\mathrm{ab}}$ & $87.47^{\mathrm{ab}}$ & $11.07^{\mathrm{bc}}$ \\
\hline & 72 & $66.69^{\mathrm{a}}$ & $74.60^{\mathrm{ab}}$ & $62.93^{\mathrm{c}}$ & $74.87^{\mathrm{c}}$ & $11.60^{\mathrm{b}}$ \\
\hline \multicolumn{7}{|l|}{$\mathrm{p}$ value } \\
\hline \multicolumn{2}{|l|}{ RS } & 0.708 & 0.016 & 0.431 & 0.420 & $\leq 0.001$ \\
\hline \multicolumn{2}{|l|}{ HA } & $\leq 0.001$ & 0.798 & $\leq 0.001$ & $\leq 0.001$ & $\leq 0.001$ \\
\hline \multicolumn{2}{|l|}{$\mathrm{RS} \times \mathrm{HA}$} & 0.875 & 0.948 & 0.730 & 0.915 & $\leq 0.001$ \\
\hline
\end{tabular}

a-c: Values within columns with different superscripts are significantly different $(\mathrm{p} \leq 0.05)$

Eggs from the floor rearing system had a higher shape index compared to organic eggs $(\mathrm{p} \leq 0.05)$, which is in agreement with the results by Kralik et al. (2013), who reported that free range rearing increased egg elongation. There was no change in egg shape index with ageing $(\mathrm{p} \geq 0.05)$, which is consistent with the results found by Sokolowitz et al. (2019) for Green-legged Partridge and Araucana genotypes. The results of the authors who found the opposite, i.e. a significant effect of hen age on this trait (Zita et al. (2009), Ledvinka et al. (2012), Rakonjac et al. (2018a and 2018b)), can be explained by the following fact: in these studies they used hybrids whose egg shape index increased with ageing, which is often not the case. In a study by Škrbić et al. (2011), the value of the egg shape index decreased with ageing $(P=-0.15)$ in Lohmann Brown hens in a conventional rearing system, while there was no change in the egg shape index with ageing in Banat Naked-Neck hens in a free-range system.

Haugh unit decreased throughout the experimental period, due to the decrease in albumen height with the ageing of hens (Rakonjac et al., 2018a). Similar results were also obtained by Ojedapo (2013) and Padhi et al. (2013). These characteristics were not significantly affected by the rearing system, which is consistent with the results reported by Lewko and Gornowicz (2011) and Kralik et al. (2013).

Both factors and their interactions had a significant effect on yolk colour $(p \leq 0.05)$. Roche values increased with hen age in the floor system, but were 
relatively constant in the organic system throughout the production cycle. Floor reared hens consumed the same amount of synthetic carotenoids in the diet throughout the experimental period, and the increasing intensity of yolk colour was the result of their greater synthesis in the body with ageing of hens (Rakonjac et al., 2018a). In organic hens, there were no synthetic carotenoids in their diet and yolk colour was much more dependent on the availability of grass at the range, which is consistent with the results published by Mugnai et al. (2009), Kucukyilmaz et al. (2012) and Kralik et al. (2013).

Table 3. Effects of rearing system and hen age on the chemical composition of eggs

\begin{tabular}{|c|c|c|c|c|c|}
\hline $\begin{array}{c}\text { Rearing } \\
\text { system } \\
(\mathrm{RS})\end{array}$ & $\begin{array}{c}\text { Hen } \\
\text { Age } \\
\text { (HA) } \\
\text { (weeks) }\end{array}$ & $\begin{array}{c}\text { Dry matter } \\
(\%)\end{array}$ & $\begin{array}{c}\text { Minerals } \\
(\%)\end{array}$ & $\begin{array}{c}\text { Protein } \\
(\%)\end{array}$ & $\begin{array}{c}\text { Lipids } \\
(\%)\end{array}$ \\
\hline \multirow{3}{*}{ Floor } & 24 & $23.58^{b c}$ & $0.89^{\mathrm{ab}}$ & $12.86^{\mathrm{a}}$ & $8.24^{\mathrm{c}}$ \\
\hline & 48 & $23.96^{b c}$ & $0.89^{\mathrm{ab}}$ & $12.27^{\mathrm{bc}}$ & $10.15^{\mathrm{ab}}$ \\
\hline & 72 & $25.89^{\mathrm{a}}$ & $0.86^{\mathrm{b}}$ & $12.60^{\mathrm{ab}}$ & $10.87^{\mathrm{a}}$ \\
\hline \multirow{3}{*}{ Organic } & 24 & $22.29^{c}$ & $0.86^{\mathrm{b}}$ & $12.94^{\mathrm{a}}$ & $7.69^{c}$ \\
\hline & 48 & $24.38^{\mathrm{abc}}$ & $0.86^{b}$ & $12.12^{\mathrm{c}}$ & $9.69^{b}$ \\
\hline & 72 & $24.85^{\mathrm{ab}}$ & $0.90^{\mathrm{a}}$ & $12.44^{\mathrm{bc}}$ & $9.90^{\mathrm{ab}}$ \\
\hline \multicolumn{6}{|l|}{$\mathrm{p}$ value } \\
\hline \multicolumn{2}{|l|}{$\mathrm{RS}$} & 0.280 & 0.691 & 0.484 & 0.038 \\
\hline \multicolumn{2}{|l|}{ HA } & 0.008 & 0.751 & $\leq 0.001$ & $\leq 0.001$ \\
\hline \multicolumn{2}{|l|}{$\mathrm{RS} \times \mathrm{HA}$} & 0.421 & 0.040 & 0.634 & 0.744 \\
\hline
\end{tabular}

a-c: Values within columns with different superscripts are significantly different $(\mathrm{p} \leq 0.05)$

Dry matter content in eggs increased with hen age $(\mathrm{p} \leq 0.05)$, while this trait was not significantly affected by rearing system $(\mathrm{p} \geq 0.05)$, which is in agreement with the results reported by Hidalgo et al. (2008) and Pavlovski et al. (2011).

Mineral content in eggs was relatively constant throughout the experimental period and was not significantly affected by rearing system, which is in agreement with the results published by Bologa et al. (2013) and Nistor et al. (2014). Only at week 72, organic eggs had a higher mineral content compared to eggs from hens aged 24 and 48 weeks.

The protein content was not significantly affected by rearing system $(\mathrm{p} \geq 0.05$ ), as in the research by Krawczyk and Gornowicz (2010) and Radu-Rusu et al. (2014). On the other hand, floor produced eggs had a higher fat content compared to organic eggs $(\mathrm{p} \leq 0.05)$, which is in agreement with the results by Matt et al. (2009) and Radu-Rusu et al. (2014), who reported that free-range eggs had a lower fat content compared to eggs from the conventional system.

With the ageing of hens, the protein content generally decreased and the fat content of eggs increased. The results are similar to those reported by Rakonjac 
et al. (2018b) for Isa Brown hens, showing not only a similar effect of rearing system on the tested traits, but also similar dynamics of age-related change in fat and protein contents in eggs under the cage, floor and organic rearing systems.

\section{Conclusion}

Based on the results of these investigations, it can be concluded that:

- Egg weight, dry matter and protein content increased, while albumen height, Haugh unit and lipid content decreased with hen age $(\mathrm{p} \leq 0.05)$;

- Eggs from the floor rearing system had a higher shape index and lipid content compared to organic eggs ( $\mathrm{p} \leq 0.05)$;

- Both factors and their interactions had a significant effect on yolk colour $(\mathrm{p} \leq 0.05)$.

\section{Acknowledgements}

The authors acknowledge the financial support from the Ministry of Education and Science of the Republic of Serbia through Project TR 31033.

\section{References}

AOAC (1990): Official methods of analysis, 13th ed. Food composition, Additives, Natural contaminants Eggs and eggs products (chapter 24). Association of Official Analytical Chemists, Inc. Arlington, Virginia, USA; 1018 pp.

Bologa M., Pop I.M., Albu A. (2013): Research on chemical composition of chicken egg from different systems of production (conventional and organic). Lucrări ȘtiinţificeSeria Zootehnie - Scientific Papers, Animal Science Series, 59 (18): 80-85.

Calik J. (2011): Genetic and production trends in New Hampshire laying hens over 8 generations. Acta Scientiarum Polonorum Zootechnica, 10 (3): 21-30.

Chung S.H., Lee K.V. (2014): Effect of hen age, storage duration and temperature on egg quality in laying hens. International Journal of Poultry Science, 13 (11): 634-636.

Hidalgo A., Rossi M., Clerici F., Ratti S. (2008): A market study on the quality characteristics of eggs from different housing systems. Food Chemistry, 106: 10311038.

Kralik Z., Radišić Ž., Grčević M., Kralik G. (2013): Comparison of table eggs quality originating from hens kept in different housing systems. Proceedings of XV European Symposium on the Quality of Eggs and Egg Products and XXI European Symposium on the Quality of Poultry Meat / Petracci, Massimiliano (ed). - Bergamo: The Italian Branch of The World's Poultry Science Association, 2013: 1-5.

Krawczyk J., Gornowicz E. (2010): Quality of eggs from hens kept in two different freerange systems in comparison with a barn system. Archiv fur Gefluegelkunde, 74: $151-157$. 
Kucukyilmaz K., Bozkurt M., Herken E.N., Cinar M., Cath A.U., Bintas E., Coven F. (2012): Effects of rearing systems on performance, egg characteristics and immune response in two layer hen genotype. Asian - Australasian Journal of Animal Sciences, 25 (4): 559-568.

Ledvinka Z., Tůmová E., Englmaierová M., Podsedníček M. (2012): Egg quality of three laying hen genotypes kept in conventional cages and on litter. Archiv fur Gefluegelkunde, 76 (1): 38-43.

Lewko L., Gornowicz E. (2011): Effect of housing system on egg quality in laying hens. Annals of Animal Science, 11 (4): 607-616.

Matt D., Veromann E., Luik A. (2009): Effect of housing systems on biochemical composition of chicken eggs. Agronomy Research, 7 (Special issue II): 662-667.

Mugnai C., Dal Bosco A., Castellini C. (2009): Effect of rearing system and season on the performance and egg characteristics of Ancona laying hens. Italian Journal of Animal Science, 88: 175-188.

Nistor (Cotfas) L.I., Albu A., Usturoi M.G. (2014): Knowledge of chemical indicators of eggs from hens reared in conventional and free range system. Bulletin UASVM Food Science and Technology, 71 (2): 119-124.

Ojedapo, L.O. (2013). Effect of age and season on egg quality traits of Isa Brown layer strain reared in derived savanna zone of Nigeria. Transnational Journal of Science and Technology, 3 (7): 48-60.

Padhi M.K., Chatterjee R.N., Haunshi S., Rajkumar U. (2013): Effect of age on egg quality in chicken. Indian Journal of Poultry Science 48 (1): 122-125.

Pavlovski Z., Škrbić Z., Lukić M., Lilić S., Krnjaja V., Staničić N., Petričević V. (2011): Comparative analysis of fatty acid profile and cholesterol content in table eggs from different genotype hens. Biotechnology in Animal Husbandry, 27 (3): 669-677.

Radu-Rusu R.M., Ustroi, M.G., Leahu A., Amariei S., Radu-Rusu C.G., Vacaru-Opris I. (2014): Chemical features, cholesterol and energy content of table hen eggs from conventional and alternative farming systems. South African Journal of Animal Science, 44 (1): 33-42.

Rakonjac S., Bogosavljević-Bošković S., Škrbić Z., Perić L., Dosković V., Petrović M.D., Petričević V. (2017): The effect of the rearing system, genotype and laying hens age on the egg weight and share of main parts of eggs. Acta Agriculturae Serbica, Vol. XXII, 44: 185-192.

Rakonjac S., Petrović M.D., Bogosavljević-Bošković S., Škrbić Z., Perić L., Dosković V. Petričević V. (2018a): Effect of age and season on production performance and egg quality of laying hens from different rearing systems. The Journal of Animal and Plant Science, 28 (6): 1602-1608.

Rakonjac S., Bogosavljević-Bošković S., Škrbić Z., Lukić M., Dosković V., Petričević V., Petrović M.D. (2018b): Quality and chemical composition of eggs affected by rearing system and hen's age. Biotechnology in Animal Husbandry, 34 (3): 343-352.

Rizzi C., Chiericato G.M. (2005): Organic farming production. Effect of age on the productive yield and egg quality of hens of two commercial hybrid lines and two local breeds. Italian Journal of Animal Science, 4 (SUPPL. 3): 160-162.

Sokołowicz Z., Dykiel M., Krawczyk J., Augustyńska-Prejsnar A. (2019): Effect of layer genotype on physical characteristics and nutritive value of organic eggs. CyTA Journal of Food, 17 (1): 11-19. 
Sørensen P., Danell B., Brenøe, U., Tuiskula-Haavisto M. (2004): A review of poultry breeding stock in the Nordic countries. Nordisk Genbank Husdyr.

Stat Soft Inc Statistica For Windows, Version 7.0. (2006): Computer program manual Tulsa.

Škrbić Z., Pavlovski Z., Lukić M., Vitorović D., Petričević V., Stojanović LJ. (2011): Changes of egg quality properties with the age of layer hens in traditional and conventional production. Biotechnology in Animal Husbandry, 27 (3): 659-667.

Van de Weerd H.A., Keatinge R., Roderick S. (2009): A review of key health-related welfare issues in organic poultry production. World's Poultry Science Journal, 65: 649-684.

Zita L., Tumova E., Štolc L. (2009): Effects of genotype, age and their interaction on egg quality in brown-egg laying hens. Acta Veterinaria Brno, 78: 85-91. 


\title{
KARAKTERISTIKE JAJA NEW HAMPSHIRE KOKOŠI NOSILJA IZ PODNOG I ORGANSKOG SISTEMA GAJENJA
}

\author{
Simeon Rakonjac ${ }^{1}$, Snežana Bogosavljević-Bošković ${ }^{1}$, Zdenka \\ $\check{S}$ Skrbić $^{2}$, Miloš Lukić ${ }^{2}$, Vladimir Dosković ${ }^{1}$, Milun D.Petrović ${ }^{1}$, Veselin \\ Petričević $^{2}$
}

${ }^{1}$ Univerzitet u Kragujevcu, Agronomski fakultet u Čačku, Srbija

${ }^{2}$ Institut za stočarstvo, Beograd-Zemun, Srbija

\section{Rezime}

Cilj ovog rada je bio da se ispita uticaj dva alternativna sistema gajenja (podnog i organskog) u tri različite faze proizvodnog ciklusa $(32,48$. i 72. nedelja starosti kokoši nosilja) na kvalitet jaja New Hampshire rase kokoši. Na 15 jaja po grupi ispitivani su parametri kvaliteta jaja (masa, indeks oblika, visina belanca, Hogove jedinice, boja žumanca) i osnovni hemijski sastav (sadržaj suve materije, minerala, proteina i masti). Sa starenjem nosilja, smanjivala se masa jaja i sadržaj suve materije i proteina, a povećavala visina belanca, Hogove jedinice i sadržaj masti $(\mathrm{p} \leq 0.05)$. Jaja iz podnog sistema gajenja imala su veći indeks oblika $\mathrm{i}$ sadržaj masti u poređenju sa organskim jajima $(\mathrm{p} \leq 0.05)$. Oba ispitivana faktora $\mathrm{i}$ njihova interakcija značajno su uticali na boju žumanca $(\mathrm{p} \leq 0.05)$.

Ključne reči: New Hampshire, sistem gajenja, kvalitet jaja, hemijski sastav, starost kokoši nosilja. 